\title{
KEEFEKTIFAN PENDEKATAN KETERAMPILAN PROSES MELALUI MEDIA VIDEO TEHADAP HASIL BELAJAR MENULIS RINGKASAN TEKS EKSPLANASI
}

\author{
Sitti Salma ${ }^{1}$ \\ Darwis Muhdina ${ }^{2}$ \\ Siti Suwadah Rimang ${ }^{3}$ \\ ${ }^{1}$ SDN 331 Borongtellu Kecamatan Gantarang Kabupaten Bulukumba \\ ${ }^{2,3}$ Magister Pendidikan Bahasa Indonesia, Universitas Muhammadiyah Makassar \\ sittisalmanasir1991@gmail.com ${ }^{1)}$ \\ darwismuhdina@unismuh.ac.id ${ }^{2}$ ) \\ sitisuwadah@yahoo.co.id ${ }^{3}$
}

\begin{abstract}
Abstrak
Tujuan penelitian ini adalah untuk mendeskripsikan (1) Tingkat hasil belajar menulis ringkasan teks eksplanasi menggunakan pendekatan keterampilan proses melalui media video siswa (2) Tingkat hasil belajar menulis ringkasan teks eksplanasi menggunakan teknik konvensional (3) Efektif tidaknya penggunaan pendekatan keterampilan proses melalui media video meningkatkan hasil belajar menulis ringkasan teks eksplanasi siswa. Penelitian merupakan penelitian survei dengan teknik eksperimen semu. Adapun populasi penelitian adalah seluruh siswa kelas V UPT SPF SDN 331 Borongtellu Kecamatan Gantarang Kabupaten Bulukumba tahun pelajaran 2020/2021. Populasi tersebut berjumlah 56 orang. Sesuai karakteristik penelitian ekperimen yang membutuhkan kelas ekperimen dan kelas kontrol, maka dalam penelitian dibuat kelas eksperimen dan kontrol diambil dua kelas secara acak yang sebelumnya diuji kemampuan menulis ringkasan yteks eksplanasi yang relatif sama. Hasil penelitian ini menunjukkan bahwa (1) Tingkat kemampuan menulis ringkasan teks eksplanasi siswa menggunakan pendekatan keterampilan proses melalui media video berada pada kategori sedang dengan nilai rata-rata 66,96. (2) Tingkat kemampuan menulis ringkasan teks eksplanasi siswa menggunakan metode konvensional berada pada kategori rendah dengan nilai rata-rata 59,68. (3) Pendekatan keterampilan proses melalui media video efektif dalam pembelajaran menulis ringkasan teks eksplanasi bagi siswa dengan nilai stat:13,336 lebih besar daripada nilai t Critical two-tail: 2,048407 pada taraf signifikan 0,05 .
\end{abstract}

Kata Kunci: Teks Ekplanasi, Keterampilan Proses, Media Video

Published by:

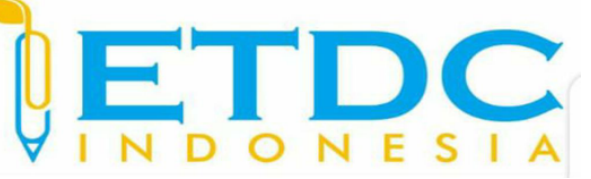

Copyright (C) 2021 The Author (s)

This article is licensed under CC BY 4.0 License

(cc) $\mathrm{BY}$ 


\section{KEEFEKTIFAN PENDEKATAN KETERAMPILAN PROSES MELALUI MEDIA VIDEO TEHADAP HASIL BELAJAR MENULIS RINGKASAN TEKS EKSPLANASI}

\section{Pendahuluan}

Bahasa merupakan alat yang paling penting dalam berkomunikasi. Pentingnya bahasa sebagai alat komunikasi dapat dilihat dari setiap aktivitas manusia yang selalu menggunakan bahasa sebagai wahana pokok. Pada proses komunikasi itu ada empat keterampilan yang berbeda. Namun saling berhubungan, yaitu menyimak, berbicara, membaca, dan menulis. Keempat aspek itu perlu mendapat perhatian sepenuhnya di dalam pembelajaran bahasa Indonesia. Dalam Kurikulum 2013 dinyatakan bahwa pembelajaran bahasa Indonesia diarahkan untuk meningkatkan kemampuan peserta didik untuk berkomunikasi dalam bahasa Indonesia dengan baik dan benar, baik secara lisan maupun tulisan, serta menumbuhkan apresiasi terhadap hasil karya kesastraan Indonesia. Selain itu tujuan utamanya adalah dapat menghargai dan bangga menggunakan bahasa Indonesia sebagai bahasa persatuan dan bahasa.

Pendekatan pembelajaraan pada kurikulum 2013 berbasis teks. Namun, ruang lingkup mata pelajaran bahasa Indonesia tetap mencangkup komponen kemampuan berbahasa dan kemampuan bersastra yang meliputi kompetensi mendengarkan, berbicara, membaca, dan menulis sebagaimana kurikulum sebelumnya. Pendekatan teks beruaya mengakomodasi keempat keterampilan berbahsa tersebut melalaui rseptif teks dan pruduksi teks atau reproduksi teks. Secara praktis salah satu kemampuan yang dibutuhkan dalam pembelajaran berbasis teks adalah menulis, baik menulis secara keseluruhan maupun sebahagian sebagai bagian dari teks tersebut.

Menulis merupakan salah satu k apuan yang perlu dimiliki oleh siswa sejak mulai sekolah dasar sampai sekolah lanjutan. Dengan memiliki kemampuan menulis cakrawala berpikir kreatif dan kritis siswa dapat berkembang. Keterampilan menulis merupakan salah satu keterampilan yang perlu dimiliki oleh siswa Madrasah Aliyah, karena bermanfaat bagi kepentingan pengembangan pada diri siswa, baik untuk melanjutkan studi mereka ke lembaga pendidikan yang lebih tinggi maupun untuk terjun ke masyarakat. Kebanyakan siswa kurang berminat dalam kegiatan menulis. Mereka tampaknya lebih menyukai berkomunikasi secara lisan karena lebih mudah dibandingkan berkomunikasi secara tertulis. Hal inilah yang menyebabkan siswa merasa asing atau terkadang tidak mampu melakukan kegiatan menulis sebagai perwujudan bentuk komunikasi tertulis. 
Kepandaian seseorang dalam menulis tidak selalu ditentukan oleh tinggi rendahnya tingkat pendidikan, tetapi banyak ditentukan oleh faktor-faktor yang memiliki hubungan dengan kemampuan menulis, yaitu kemampuan menyimak, kemampuan berbicara, dan kemampuan membaca. Jelaslah bahwa ketiga faktor tersebut merupakan bagian dari sejumlah faktor yang berpengaruh terhadap kemampuan menulis seseorang. Pentingnya pembelajaran menulis dapat dilihat dari beberapa hasil penelitian antara lain: Penelitian Laboh (2011) menunjukkan bahwa strategi guru dalam pembelajaran menulis kreatif masih bersifat klasikal (penyampaian bersifat lisan) atau belum terlaksana sesuai model pembelajaran sehingga masih diperlukan penyesuaian (adaptasi) dan Kadir (2010) hasil penelitiannya menunjukkan bahwa materi pembelajaran disajikan oleh guru melalui dua macam strategi, yaitu: (1) materi pelajaran didiktekan sendiri, materi diambil dari "Terampil Berbahasa Indonesia", (2) materi diambil dari satuan pelajaran dan disusun dalam bentuk satuan pelajaran. Materi pelajaran yang disajikan masih sangat teoretis, begitu pula dalam hal pengembangan tulisan siswa, guru sangat memperhatikan ejaan dan tanda baca juga sangat teoretis karena guru hanya memperkenalkan macam-macam ejaan yang ada dan penggunaan tanda titik, koma, tanda tanya, huruf kapital dan penulisan kata gabung. Kedua hasil penelitian memberikan indikator bahwa betapa pentingnya pengajaran menulis bagi siswa baik di sekolah.

Untuk mencapai hal-hal tersebut diperlukan pembelajaran menulis siswa, untuk dikembangkan agar dapat lebih mampu memaparkan isi tulisan, pengorganisasian tulisan, pemakaian kalimat secara efektif, dapat menggunakan pilihan kata (diksi) yang tepat, pemakaian ejaan dan tanda baca, serta dapat membuat paragraf yang baik. Dalam mengkomunikasikan ide-ide atau gagasan-gagasan, argumen-argumen serta mampu memberi bentuk kepada segala sesuatu yang ia rasakan, berapa rangkaian kata secara tertulis, tersusun dengan sebaik-baiknya sehingga gagasannya itu dapat dipahami dan dapat dipetik manfaatnya dengan mudah oleh orang lain.

Salah satu kemampuan menulis yang diharapkan di sekolah dasar adalah membuat ringkasan teks eksplanasi. Meskipun kemampuan ini tampak mudah karena hanya meringkas teks, namun ternyata siswa juga mengalami kesulitan dalam pelaksanaannya. Selain mempersyatakan keteraampilan menulis secara umum, juga harus memperhatokan konsep dan strategi membuat atau persyaratan ringkasan teks. Selain itu, siswa umumnya merasa asing dengan teks eksplanasi. Kriteria ringkasan teks tetu harus meperhatikan beberapa hal seperti; (1) tetap mempertahankan urutan pikiran dan pendekatan penulis asli.(2) tidak boleh mengandung hal baru, pikiran, atau opini dari pembuat ringkasan, baik yang dimasukkan secara sadar maupun tidak sadar; (3) harus disampaikan dengan suara asli penulis, bukan dengan suara 
pembuat ringkasan. Hal ini tetu membutuhkan keteram[ilan tertentu yang terlatih dan cermat oleh siswa sekolah dasar.

Mengingat pentingnya pengajaran menulis tersebut, seorang guru harus memahami aspek-aspek menulis, memiliki kemampuan menulis yang mandiri. Seorang guru diharapkan menggunakan suatu pendekatan yang efektif yang digunakan dalam pengajaran bahasa Indonesia khususnya dalam menulis ringkasan ekplanasi. Salah satu pendekatan yang dianggap edektif adalah menulis ringaksan adalah pendekatan keterampilan proses, karena dengan pendekatan ini guru membimbing siswa secara terarah. Di samping itu, pendekatan ini memberikan motivasi kepada siswa untuk mengamati lingkungannya. Dengan pengamatan tersebut tentunya siswa akan termotivasi untuk menulis deskriptif berdasarkan objek yang telah diamati di bawah bimbingan guru tersebut. Penerapan pendekatan keterampilan proses dalam pembelajaran bukan merupakan hal yang wajar dan harus dianut oleh guru dalam pembelajarannya. Untuk dapat menerapkan pendekatan keterampilan proses dalam pembelajaran dengan strategi pelaksanaan yang kreatif dan inovatif

Oleh karena itu, rumusan masalah penelitian ini meliputi: (1) Bagaimanakah tingkat hasil belajar menulis ringkasan teks eksplanasi menggunakan pendekatan keterampilan proses melalui media video?; (2) Bagaimanakah tingkat hasil belajar menulis ringkasan teks eksplanasi menggunakan teknik konvensional siswa?; dan (3) Apakah penggunaan pendekatan keterampilan proses melalui media video efektif dalam meningkatkan hasil belajar menulis ringkasan teks eksplanasi siswa?

\section{Metode Penelitian}

Penelitian ini merupakan jenis penelitian deskriptif-eksperimen yang berupaya mengungkap data apa adanya melalui eksperimen dengan jenis kuantitatif. Metode eksperimen ini pada prinsipnya adalah mengujicobakan penggunaan dua variabel yakni pendekatan keterampilan proses melalui media video dalam menulis ringkasan teks eksplanasi. Penelitian ini dilakukan pada satu kelas ekperimen dan satu kelas kontrol. Pada kelas eksprimen diberikan pembelajaran menulis ringkasan teks eksplanasi menggunakan pendekatan keterampilan proses melalui media video sedangkan pada kelas kontrol diberikan pembelajaran konvensional berupa penjelasan konsep, pemberian contoh dan latihan membuat ringkasan teks eksplanasi

\subsection{Populasi dan Sampel}

Populasi penelitian ini adalah seluruh siswa kelas V UPT SPF SDN 331 Borongtellu Kecamatan Gantarang Kabupaten Bulukumba tahun pelajaran 2020/2021 sejumlah 64 orang. 
Sesuai dengan karakterisktik penelitian, maka seluruh populasi dipilih sebagai objek penelitian. Namun, populasi itu dibagi dua kelas, yaitu sebuah kelas eksperimen dan sebuah kelas kontrol. Untuk keperluan penelitian kelompok tersebut terlebih dahulu menyamakan tingkat kemampuannya dalam menulis ringkasan dengan cara tugas membuat ringkasan

\subsection{Pengumpulan Data}

Data dala penelitian ini merupakan jenis data kuantitatif yakni jenis data yang dapat diukur atau dihitung secara langsung sebagai variabel angka atau bilangan. Data tersebut berupa angka-angaka hasil tes kemampuan memulis ringkasan teks eksplanasi siswa sampel. Sumber data penelitian ini adalah hasil tes menulis ringkasan teks eksplanasi siswa kelas V UPT SPF SDN 331 Borongtellu Kecamatan Gantarang Kabupaten Bulukumba tahun pelajaran 2020/20213. Teknik pengumpulan data dalam penlitian ini mengunakan teknik tes dengan cara siswa sampel diberikan tugas menulis ringkasan terks eksplanasi setelah diintervensi dengan pembelajaran pendekatan keterampilan proses melalui media video bagi kelas ekperimen dan pembelajaran menulis ringkasan terks eksplanasi melalui teknik konvensional bagi kelas kontrol.

\subsection{Definisi Operasional}

Untuk memperjelas pemahaman dan menghindari salah penafsiran dalam penulisan ini maka dikemukakan definisi operasional variabel sebagai berikut.

1. Pendekatan keterampilan proses melalui media video adalah latihan kemampuan mental, fisik dan sosial yang mendasar sebagai penggerak kemampuan-kemampuan yang lebih tinggi yang dikerjakan terus menerus dibantu dengan media video yang berisi teks ekplanasi yang alan dicermati secara mudah oleh siswa..

2. Metode konvesional adalah cara membelajarankan menulis ringkasan teks eksplanasi sebagaimana yang sudah lazim seperti ceramah tentang unsur menulis menulis ringkasan teks eksplanasi dengan menyodorkan contoh, tema atau topik dan teks yang aan diringkas.

3. Hasil belajar menulis ringkasan teks eksplanasi adalah produk hasil menulis ringkasan teks eksplanasi dalam bentuk karangan yang diberi nilai kuantitatif.

\subsection{Analisis Data}

Data hasil belajar menulis ringkasan teks eksplanasi menggunakan pendekatan keterampilan proses melalui media video pada kelas eksperimen, maupun teknik konvensional dianalisis dengan teknik presentasi (\%) dengan rumus: n/Nx100 untuk rentang 10-100. Data keefektifan pembelajaran menulis ringkasan teks eksplanasi menggunakan pendekatan keterampilan proses melalui media video diolah menggunakan statistik inferensial dengan uji 
$t$ (t-test) dengan bantuan komputer fasilitas komputer fasilitas uji t data Analysis pada two sample assuming equal variances pada program exel.

\section{Hasil dan Pembahasan}

\subsection{Tingkat hasil belajar menulis ringkasan teks eksplanasi siswa kelas menggunakan} pendekatan keterampilan proses melalui media video

Data tingkat hasil belajar menulis ringkasan teks eksplanasi siswa kelas V UPT SPF SDN 331 Borongtellu Kecamatan Gantarang Kabupaten Bulukumba menggunakan pendekatan keterampilan proses melalui media video dapat dilihat pada ringkasan nilai konversi 1-100 dari skor mentah dapat dilihat pada Tabel 1 berikut.

Tabel 1. Statistik nilai hasil belajar menulis ringkasan teks eksplanasi siswa menggunakan pendekatan keterampilan proses melalui media video

\begin{tabular}{cc}
\hline Statistik & Nilai Statistik \\
\hline Subjek & 28 \\
\hline Nilai Ideal & 100 \\
\hline Nilai Tertinggi & 75 \\
\hline Nilai Terendah & 52 \\
\hline Nilai Rata-rata & 66,96 \\
\hline
\end{tabular}

Tabel 1 menunjukkan bahwa nilai rata-rata hasil belajar menulis ringkasan teks eksplanasi siswa kelas V UPT SPF SDN 331 Borongtellu Kecamatan Gantarang Kabupaten Bulukumba menggunakan pendekatan keterampilan proses melalui media video dengan subjek/responden penelitian 28 orang siswa sebesar 66,96. Nilai yang dicapai responden tersebar dengan nilai tertinggi 75,56 dan nilai terendah 52 dari nilai tertinggi yang mungkin dicapai 100 dan nilai terendah yang mungkin dicapai 0. Selanjutnya nilai tersebut dikaitkan dengan kategorisasi nilai sebagai berikut (Lihat Tabel 2):

Tabel 2. Kategorisasi Nilai

\begin{tabular}{cc}
\hline Nilai & Kategori \\
\hline $0-40$ & Sangat rendah \\
\hline $41-55$ & Rendah \\
\hline $56-70$ & Sedang \\
\hline $71-85$ & Tinggi \\
\hline $86-100$ & Sangat tinggi \\
\hline
\end{tabular}

Berdasarkan kategorisasi di atas (Tabel 2), maka dinyatakan bahwa nilai hasil belajar menulis ringkasan teks eksplanasi siswa kelas V UPT SPF SDN 331 Borongtellu Kecamatan Gantarang Kabupaten Bulukumba menggunakan pendekatan keterampilan proses melalui media video berada pada kategori sedang. 


\subsection{Tingkat hasil belajar menulis ringkasan teks eksplanasi siswa menggunakan metode}

\section{konvensional}

Data tingkat hasil belajar menulis ringkasan teks eksplanasi siswa kelas V UPT SPF SDN 331 Borongtellu Kecamatan Gantarang Kabupaten Bulukumba metode konvensional dapat dilihat pada ringkasan nilai konversi 1-100 dari skor mentah dapat dilihat pada Tabel 3 berikut.

Tabel 3. Statistik nilai hasil belajar menulis ringkasan teks eksplanasi siswa metode konvensional

\begin{tabular}{cc}
\hline Statistik & Nilai Statistik \\
\hline Subjek & 28 \\
\hline Nilai Ideal & 100 \\
\hline Nilai Tertinggi & 62 \\
\hline Nilai Terendah & 44 \\
\hline Nilai Rata-rata & 59,68 \\
\hline
\end{tabular}

Tabel 3 menunjukkan bahwa nilai rata-rata hasil belajar menulis ringkasan teks eksplanasi siswa kelas V UPT SPF SDN 331 Borongtellu Kecamatan Gantarang Kabupaten Bulukumba metode konvensional dengan subjek/responden penelitian 28 orang siswa sebesar 59,68. Nilai yang dicapai responden tersebar dengan nilai tertinggi 62 dan nilai terendah 44 dari nilai tertinggi yang mungkin dicapai 100 dan nilai terendah yang mungkin dicapai 0 . Selanjutnya nilai tersebut dikaitkan dengan kategorisasi nilai sebagai berikut (Lihat Tabel 4):

Tabel 4. Kategorisasi Nilai

\begin{tabular}{cc}
\hline Nilai & Kategori \\
\hline $0-40$ & Sangat rendah \\
\hline $41-55$ & Rendah \\
\hline $56-70$ & Sedang \\
\hline $71-85$ & Tinggi \\
\hline $86-100$ & Sangat tinggi \\
\hline
\end{tabular}

Berdasarkan kategorisasi di atas, maka dinyatakan bahwa nilai hasil belajar menulis ringkasan teks eksplanasi siswa kelas V UPT SPF SDN 331 Borongtellu Kecamatan Gantarang Kabupaten Bulukumba sesudah menggunakan pendekatan keterampilan proses melalui media video berada pada kategori rendah.

\subsection{Uji Keefektifan/ Uji hipotesis}

Untuk menentukan keefektifan pendekatan keterampilan proses melalui media video dalam pembelajaran menulis ringkasan teks eksplanasi siswa kelas V UPT SPF SDN 331 Borongtellu Kecamatan Gantarang Kabupaten Bulukumba maka data dari sebelum dan sesudah penerapan menggunakan pendekatan keterampilan proses melalui media video dianalisis dengan menggunakan komputer fasilitas uji t Data Analysis pada two sample assuming equal variances pada program exel

Secara deskriptif data kedua data tersebut dapat diringkas sebagai berikut. 
t-Test: Paired Two Sample for Means

\begin{tabular}{lrr}
\hline & Variable 1 & \multicolumn{1}{c}{ Variable 2 } \\
\hline Mean & 67,03703704 & 54,84615385 \\
Variance & 52,11396011 & 26,85538462 \\
Observations & 27 & 26 \\
Pearson Correlation & 39,73230546 & \\
Hypothesized Mean Difference & 0 & \\
Df & 51 & \\
t Stat & 7,038723552 & \\
$\mathrm{P}(\mathrm{T}<=\mathrm{t})$ one-tail & $2,36376 \mathrm{E}-09$ & \\
$\mathrm{t}$ Critical one-tail & 1,67528495 & \\
$\mathrm{P}(\mathrm{T}<=\mathrm{t})$ two-tail & $4,72752 \mathrm{E}-09$ & \\
$\mathrm{t}$ Critical two-tail & 2,00758377 & \\
\end{tabular}

\subsection{Pengujian hipotesis}

Berdasarkan hasil pengolahan dan penyajian data, maka dapat dijelaskan pengujian hipotesis bahwa hasil analisis data diperoleh nilai “ $t$ ” stat adalah 7,038723552 sedangkan nilai t Critical two-tail adalah 7,038723552 maka dapat dijelaskan nilai stat lebih besar daripada nilai t Critical two-tail (stat:13,336> t Critical two-tail: 2,048407) pada taraf signifikan 0,05. Atau dapat juga dilihat pada nilai $\mathrm{P}(\mathrm{T}<=\mathrm{t})$ two-tail sama dengan 4,72752 dan nilai signifikansi 0,05, maka dapat dijelaskan nilai $\mathrm{P}(\mathrm{T}<=\mathrm{t})$ two-tail lebih besar daripada nilai signifikansi $(\mathrm{P}(\mathrm{T}<=\mathrm{t})$ two-tail: 4,72752>0,05). Hal menunjukkan bahwa hipotesis nol yang berbunyi: "Pendekatan keterampilan proses melalui media video tidak efektif meningkatkan hasil belajar menulis ringkasan teks eksplanasi siswa kelas V UPT SPF SDN 331 Borongtellu Kecamatan Gantarang Kabupaten Bulukumba ditolak. Hipotesis alternatif berbunyi "Pendekatan keterampilan proses melalui media video efektif dalam pembelajaran menulis ringkasan teks eksplanasi siswa kelas V UPT SPF SDN 331 Borongtellu Kecamatan Gantarang Kabupaten Bulukumba" diterima. Dengan demikian, dapat dikemukakan bahwa Pendekatan keterampilan proses melalui media video efektif meningkatkan hasil belajar menulis ringkasan teks eksplanasi siswa kelas V UPT SPF SDN 331 Borongtellu Kecamatan Gantarang Kabupaten Bulukumba pada taraf kepecayaan 95\%.

\subsection{Pembahasan}

Berdasarkan hasil penelitian ini dapat dipahami bahwa salah satu cara meningkatkan pembelajaran menulis ringkasan teks eksplanasi khususnya siswa sekolah dasar, adalah menggunakan Pendekatan keterampilan proses melalui media video. Secara rasional Pendekatan keterampilan proses melalui media video dapat mempermudah siswa dalam mengembangkan pemahaman terhadap teks yang akan diringkas karena detailnya dapat 
divisualisasi melalui video. Selain itu, keterampilan proses dapat memberi pengalaman siswa dalam berbagai aktivitas yang akan membantu dirinya dalam membangun keterampilan meringkas, termasuk teks eksplanasi. Pengajaran menulis, termasuk ringkasan teks eksplanasi yang selama ini dianggap kurang sulit, dapat dilatihkan dengan menggunakan pendekatan keterampilan proses melalui media video untuk merangsang pemikiran dalam mengorganisasi tulisan selain memberi daya tarik dalam pembelajaran karena menggunakan media.

Permasalahan pokok dalam penelitian ini adalah pemanfaatan pendekatan keterampilan proses dalam meningkatkan pembelajaran menulis ringkasan teks eksplanasi. Ada berbagai keterampilan dalam keterampilan proses. Keterampilan-keterampilan tersebut terdiri dari keterampilan-keterampilan terintegrasi (integrated skill). Keterampilan dasar terdiri dari enam keterampilan, yakni: mengobservasi, mengklasifikasi, memprediksi, menyimpulkan, dan mengkomunikasikan. Sedangkan keterampilan-keterampilan terakreditasi terdiri atas: mengidentifikasi variabel, membuat tabulasi data, menyajikan data dalam bentuk grafik, menggambarkan hubungan antarvariabel, mengumpulkan dan mengolah data, menganalisis penelitian, menyusun hipotesis, mendefinisikan variabel secara operasional, merancang penelitian, dan melaksanakan eksperimen. (Dimyati, 2016).Keseluruhan proses itu digunakans secara sederhana dalam membuat ringkasan teks eksplanasi.

Penerapan pendekatan keterampilan proses dalam pembelajaran menulis ringkasan teks eksplanasi menekankan kerja sama antarsiswa dalam satu kelompok kecil yang sifatnya heterogen. Wujud kerja sama dalam kelompok tersebut tidak hanya menekankan pada penyelesaian tugas-tugas, tetapi juga melatih siswa untuk mampu memberikan dan menerima kritikan dan saran dalam bentuk lisan, serta menanamkan rasa tanggung jawab pada diri sendiri. Mesakipun dalam penelitian ini digunakan seraca online (dalam jaringan) akan tetapi kerja sama tersebut tetap terjalin secara virtual. Pemanfaatan pendekatan keterampilan proses melalui media video dalam penelitian terdapat beberapa keunggulan sebagaimana yang dipaparkan oleh Syaidiman (2018) antara lain (1) secara tidak langsung terjadi proses pembelajaran bidang studi lain dan pembahasan aspek pembelajaran bahasa Indonesia lainnya secara terencana dan sistematis (lintas bidang studi dan lintas unit/aspek pembelajaran bahasa); (2) dapat memupuk keberanian, sikap ilmiah, pikiran kritis siswa; (3) dapat menimbulkan dampak pengiring yang positif seperti; belajar diskusi, menyimak,dan sebagainya.

Hasil penelitian ini sesuai dengan konsep yang dikemukakan oleh Susilana (2017:15) bahwa kelebihan media video adalah; (1) Sifatnya konkrit, lebih realistis dibandingkan media verbal; (2) Video dapat mengatasi keterbatasan ruang dan waktu; (3) Video dapat mengatasi keterbatasan pengamatan termasuk gerak; (4) Dapat memperjelas suatu masalah dalam bidang 
apa saja dan usia berapa saja; dan (5) Murah dan mudah membuat dan menggunakannya di era digital sekarang ini. Sulaiman (2015:57) mengemukakan rangsangan gambar atau video, membuat peserta didik mampu mengubah kalimat-kalimat yang kering menjadi deskripsi yang menakjubkan sebagai pemikiran brilian. Demikian hal Harun (2013) menjelaskan bahwa gaya belajar audio visual siswa sangat dominan karemna menggunakan hampir sel;uruh unsur seperti mencermati, menyimak, mengamati, membaca, menganalisis dan menyimpulkan objek yang dipelajari.

\section{Kesimpulan dan Saran}

Unjuk menjawab pertanyaan penelitian diuraikan sebagai berikut: Tingkat kemampuan menulis ringkasan teks eksplanasi siswa menggunakan pendekatan keterampilan proses melalui media video berada pada kategori sedang dengan nilai rata-rata 66,96; (2) Tingkat kemampuan menulis ringkasan teks eksplanasi siswa menggunakan metode konvensional berada pada kategori rendah dengan nilai rata-rata 59,68; (3) Pendekatan keterampilan proses melalui media video efektif dalam pembelajaran menulis ringkasan teks eksplanasi bagi siswa dengan nilai stat:13,336 lebih besar daripada nilai t Critical two-tail: 2,048407 pada taraf signifikan 0,05. Berdasarkan kesimpulan maka dalam penulisan ini dikemukakan saran sebagai berikut: ((1) Sebaiknya pendekatan keterampilan proses melalui media video diterapkan dalam pembelajaran menulis ringkasan teks eksplanasi di SD untuk meningkatkan kemampuan menulis ringkasan teks eksplanasi siswa; (2) Sebaiknya pendekatan keterampilan proses melalui media video ini tidak dijadikan satu-satunya metode yang dianggap efektif tetapi guru diharapkan mengembangkannya untuk mencari alternatif lainnya untuk meningkatkan pembelajaran menulis ringkasan teks eksplanasi di SD; dan (3) Penelitian ini diharapkan menjadi dasar dalam mengadakan penelitian lanjutan, sehingga dapat ditemukan upaya operasional dalam meningkatkan kemampuan menulis ringkasan teks eksplanasi siswa.

\section{DAFTAR PUSTAKA}

Akhadiah, Sabarti dkk. 2012 Pembinaan Kemampuan Menulis Bahasa Indonesai. Jakarta: Erlangga.

Dimyati dan Muyiono. 2012. Srategi Belajar-Mengajar. Jakarta: Depdikbud.

Haris, Abdul . 2013. Evaluasi PembelajaranBahasa Indonesia. Yogyakarta: Multi Pressindo.

Harun, Mukhtar. 2013. Media Pendidikan. Jakarta: Gema Press.

Hasan, Ahmad. 2013. Media Pembelajaran.Jakarta: Insan Press 
Kadir K, Abdul. 2010. Pengembangan Model Pembelajaran Menulis Deskriptif Siswa Kelas II SMP Kemala Bayangkari Disamakan Maksaar. Tesis tidak diterbitkan. Makassar: Program pascasarjana Uninersitas Negeri Makassar

Laboh. 2011. Strategi Pembelajaran Menulis Kreatif pada Siswa Madrasah Aliyah di kota Kendari. Jurnal Eksistensi Vol.II Tahun 2015.

Mahsun, 2018. Pembelajaran Bahasa Indonesia Berbasis Teks. Jakarta: Depdikbud.

Marahimin, Ismail. 2010. Menulis Kreatif. Jakarta: UI Press

Natia, I.K. 2012. Bimbingan Mengarang. Surabaya: Arkola

Nurgiantoro, Burhan. 2014. Penilaian dalam Pengajaran Bahasa dan Sastra. Yogyakarta: BPFE.

Nurhayati, Sitti. 2016. Efektivitas Pendekatan Ketrampilan Proses Berbasis Outbond: Jurnal Ilmu Kalam: Vol. VI. Januari 2016

Priyatni, 2014. Memulai Menulis. Jogjakarta; Analisa

Rahim, Ahmad. 2014. Pengelolaan Pengajaran. Jakarta: Rineca Cipta.

Subaedah, Sitti. 2015. Efektivitas Pendekatan Ketrampilan Proses Efektif dalam Pembelajaran Menulis Teks Prosedur di SD Negeri Sidodadi Polewali Mandar: Jurnal Tut Wuri Handayani, Vol. II. Agustus 2015

Sulaiman. 2015. Media Pendidikan. Jakarta: Rajawali Press.

Sutarso, Hadi. 2019. Proses Pembelajaran. Jakarta: Gema Press.

Syaidiman 2018. Media Pembelajaran Teori dan Aplikasi Jakarta: Matabaca

Tarigan, Henry Guntur. 2013. Menulis sebagai Suatu Keterampilan Berbahasa. Bandung: Angkasa.

Zaini. 2011. Strategi Pembelajaran Aktif. Yogyakarta :CTSD 